\title{
Community Satisfaction toward Posdaya Assistance Program in West Java
}

\author{
1DWI SADONO, ${ }^{2}$ SAHARUDDIN, ${ }^{3}$ YUSALINA, 4BURHANUDDIN, ${ }^{5}$ TINTIN SARIANTI \\ ${ }^{1,2,}$ Departemen Sains Komunikasi dan Pengembangan Masyarakat, Fakultas Ekologi Manusia IPB, \\ Jln. Kamper Kampus IPB Dramaga Bogor \\ ${ }^{345}$ Departemen Agribisnis, Fakultas Ekonomi dan Manajemen IPB, \\ Jln. Kamper Kampus IPB Dramaga Bogor \\ email: ${ }^{1}$ d_sadono@yahoo.com; ${ }^{2}$ sagasaharuddin@gmail.com; ${ }^{3}$ yusalina0115@gmail.com; \\ ${ }^{4}$ burhanipb@gmail.com; ${ }^{5}$ t_sarianti@yahoo.com
}

\begin{abstract}
Posdaya is a community empowerment post managed by and for the community. In an effort to strengthen Posdaya, assistance is given during a certain period of time. The purpose of this study was to analyze the pattern of assistance given to Posdaya and the degree of satisfaction as perceived by Posdaya over the assistance pattern. The study was conducted in 25 Posdaya in Bogor City and Bogor Regency, involving 125 respondents of Posdaya managing personnel. The study results showed that Posdaya assistance has been given by several Universities and the Local Government in Bogor. Assistance to Posdaya has been adequately improved the capacity of personnel to manage and enhance Posdaya. The resulted analysis on the degree of importance and performance found that the aspects of assistance (enabling, strengthening, protection, advocacy, maintenance, time and finance) had a high level of suitability, except for the aspect of assistance frequency. The results of CSI analysis showed that Posdaya personnel were quite satisfied with the pattern of assistance given. Three aspects of assistance need to be improved at a low priority, especially frequency, time and financial cost of assistance.
\end{abstract}

Keywords: posdaya, community empowerment, degree of satisfaction with assistance

\section{Introduction}

Posdaya is a means of community empowerment independently conducted from, by and for the community. It is a form of togetherness with its members by doing real activities in the development movement at the bottom level of neighborhood, namely Rukun Tetangga (neighborhood), Rukun Warga (groups of neighborhoods), and villages. Community participation as a social capital in development is needed. Nasution et al. (2014) states that rural households (especially poor households) can increase access to social capital by participating in community activities.

Posdaya conducts family empowerment activities, especially in four pillars, namely: to expand the scope and quality of education, improve access to health services, develop the economy and improve the environment.
The measure of Posdaya success is that every family participates fully and tries to implement its eight (8) main functions, which are derived from the Millennium Development Goals (MDGs) targets, followed by Sustainability Development Goals (SDGs) or Human Development Index (HDI)). However, in early efforts, Posdaya can focus its activities on four main targets of HDI: entrepreneurship or economics, education and skills, family planning and health, and environment.

The main characteristic of Posdaya is independence and self-reliance. The success or failure of Posdaya is determined by the willingness of the people to move forward, not by the amount of fund or material inventory. Its existence is increasingly accepted and adapted by the community because it is considered in line with the development programs designed by the government. Adequate adaptation of Posdaya in the community has brought

Received: January 15, 2017, Revision: March 08, 2017, Accepted: May 19, 2017

Print ISSN: 0215-8175; Online ISSN: 2303-2499.

Accredited by DIKTI. SK Kemendikbud, No.040/P/2014, valid 18-02-2014 until 18-02-2019, Indexed by DOAJ 
about a rapid growth in Posdaya. Currently there are more than 20.000 Posdaya all over Indonesia (Muljono 2014). However, Posdaya's development is still diverse some Posdaya have an independent status and many others have a developing status (Muljono 2014). This condition will certainly affect the role of Posdaya in empowering families or communities. The purpose of Posdaya establishment is to revitalize social capital, such as cooperative life in society to help with an integrated family empowerment and to build a happy and prosperous family (Suyono and Haryanto 2007).

To strengthen the role of Posdaya in the community, assistance is given during a certain period. Assistance is one form of extension to prepare the community, in this case the personnel and members of Posdaya so that they will have knowledge, be willing, and able to acquire certain competencies to become more empowered and increasingly prosperous.

"Pemberdayaan" is the word translated from the English word, empowerment, a concept born from people's thinking in Western culture, especially in Europe. In its development, the definition of empowerment is formulated differently by social scientists depending on their own perspectives. Empowerment in the perspective of community development is always associated with the concept of independence, participation, networking and justice. This is as stated by Ife and Tesoriero (2002) that empowerment aims to increase the power or strength of the powerless (weak) group. All the potential possessed by the less fortunate individual or group is improved, activated, and developed to become empowered to build itself.

Slamet (2000) states that community empowerment is another expression for the goal of development extension. Community empowerment is an effort to make people able, empowered, understand, motivated, have opportunity, see opportunity, can take advantage of opportunity, have energy, able to cooperate, know various alternatives, able to take decisions, dare to face risks, and able to act according to the situation. Adequate power, strength and capacity of the community will encourage people to access productive resources, to become independent in decision making and confident in taking actions. Empowerment will produce a dynamic and progressive society in a sustainable way because it is based on the presence of intrinsic and extrinsic motivation.

One component of Posdaya empowerment activities that have an important role in its success is the presence of empowerment worker, assistant or facilitator. The role of Posdaya assistant is, among others, carried out by the universities or by appropriate field staff from the local government such as PLKB, PPL, Midwife, and others (Muljono et al., 2011). Assistance is intended to accelerate and maintain the spirit of society in revitalizing social capital, namely cooperation to create sustainable empowerment. This assistance is expected to improve the quality of services given by Posdaya to produce a certain level of satisfaction in the community.

Community satisfaction is interpreted as a behavioral reaction after receiving services from partner Posdaya. Satisfaction or dissatisfaction of the community is determined by the perception and expectations of the community. The perception of the product or service itself is influenced by the experience of the community when trying a product or receiving a service. This will certainly affect the decision making for a continued use of the same services and will affect the delivery of messages and impressions to others about the services provided.

Community satisfaction of a service is determined by the level of community interest before using the services, compared with the resulted perception of the service after using the service. The level of community interest is the belief before trying or buying a service product and will become the reference standard in assessing the performance of the service product.

The problem often encountered is that Posdaya officials wrongly estimate the level of expectation or wishes of the customers, causing it to be far below the customer's expectation. This has caused the quality of service not achieved as expected by the customers, as found by Sadono et al. (2014a). The community is generally less supportive of Posdaya because its implemented program and its impact on the social development have not been sufficiently felt (Muljono 2014). For this reason, a breakthrough is needed in the pattern of assistance given so far to Posdaya to generate good public perception, suitable elements of service to the community satisfaction, Posdaya benefits for the community especially in education, economy, health and environment. 
Based on the background and the results of previous studies (Agustina 2011, Muljono et al., 2009, Muljono et al. 2010, Rahmawati 2012, Virianita et al., 2011), it is necessary to conduct a study of Posdaya assistance and the degree of community satisfaction with Posdaya assistance activities. Therefore, the research problem formulated is how the assistance given to Posdaya is implemented and how the level of satisfaction of the Posdaya staff over the assistance.

In general, the study conducted in the town and regency of Bogor aims to analyze the assistance program conducted on Posdaya. Specifically, the objectives of this study are: (1) to analyze the assistance program conducted on Posdaya; and (2) to determine the level of satisfaction of Posdaya officials toward the assistance program.

\section{Research Methods}

This research was conducted in Bogor Regency and Bogor City. Both regions are the sites of Posdaya development program. Given the Posdaya distribution that has been developed in the research sites, the number of Posdaya samples selected was 15 Posdaya located in Bogor Regency and 10 Posdaya in Bogor City. Field research activities are conducted for two periods, from July to August 2013 and reviewed in 2015.

This study uses two types of data, namely secondary and primary. The secondary type is in the form of important data and documents related to the studied issues, which available in Posdaya. The primary type is in the form of data related to the implementation of Posdaya assistance and collected during the field visit to the study location by using a structured interview (survey) with the recipients of the assistance program.

Other primary data also collected were from interviews with key informants related to the implemented assistance to obtain more and better information, especially on the problems encountered in the implemented assistance. In-depth interviews were also conducted to identify an alternative problem solving from the point of view of Posdaya officials. In addition, focus group discussions (FGDs) were also held with several program managers and beneficiaries.

Respondents in this study are those members who get Posdaya assistance. Posdaya taken as the research sites are: (1)
Posdaya that has existed for at least 2 years; and (2) each Posdaya represents one of the assistance patterns implemented so far.

The total number of respondents is 125 people. From each Posdaya sample, five respondents were taken, consisting of one coordinator and four heads of sections (economy, education, health and environment).

The data on the implemented assistance at Posdaya was analyzed by using a frequency tabulation. Satisfaction analysis on the implemented assistance at Posdaya used IPA (Importance Performance Analysis) method to determine the level of performance and the community interest towards the implemented assistance. The performance level and the community interest were measured by Differential Semantic scales on the score of 1-4, whereby score 1 shows the lowest level of performance and interest and score 4 shows the highest level of performance and interest.

The IPA analysis includes several aspects. The first is an analysis of the level of performance and interest felt by the Posdaya personnel towards the elements of assistance services provided in the Posdaya activities (education, health, economic and environment) in each region, stated in average scores of assessments given by Posdaya personnel on the performance and interest they felt related to Posdaya assistance activities. The second is an analysis of the suitability level of assistance elements to the performance and interest, which is the ratio between the average assessment score of performance and the average assessment score of interest expressed in percentage. The score value is said to have met the suitability level if the level of community performance is more than or equal to the level of community interest.

The third is the gap analysis between the performance and the interest of the assistance. This was conducted to obtain information on how far the elements in the assistance has met the needs of the community. The gap was obtained by measuring the difference between the average score of interest and the average score of performance as perceived by Posdaya personnel.

The fourth is an analysis of the factors of dissatisfaction and solutions offered. From the resulted analyses, a priority order was then made, described in Cartesian Diagram (Figure 1). 


\section{Satisfaction Score}

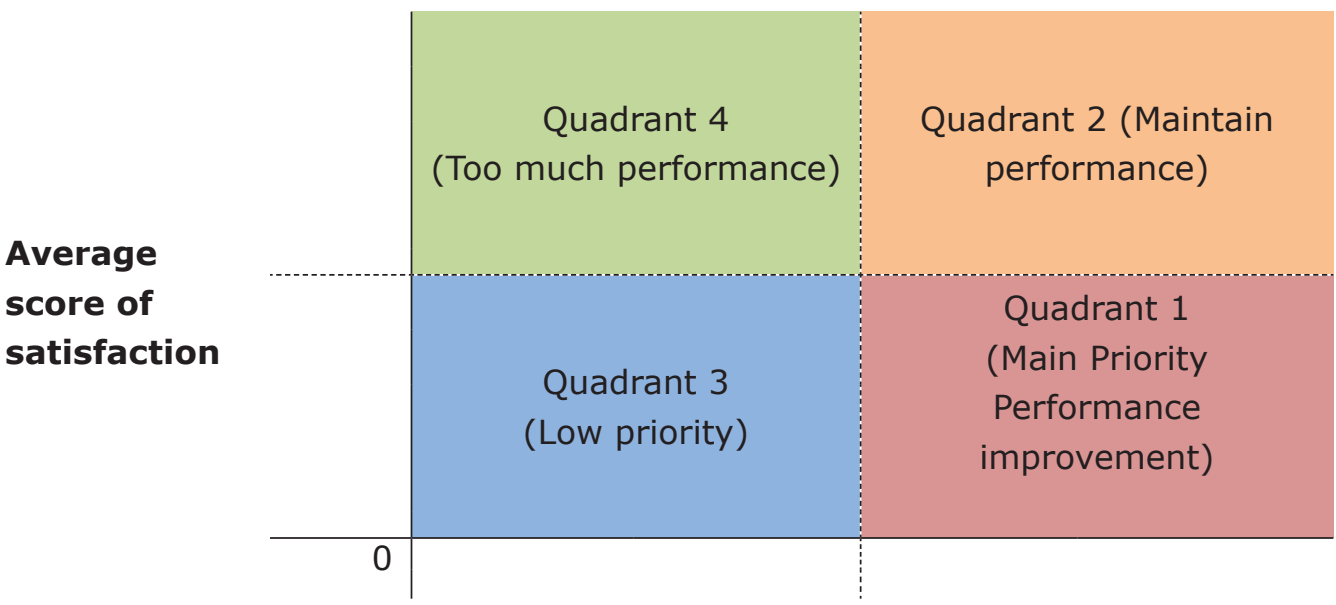

Average score of interest

Figure 1. Cartesian Diagram (Supranto, 2011)

The analysis of priority sequence in improvement efforts was made by considering the average score, the percentage of suitability and the gap between the level of performance and interest. The priority sequence is described in the Cartesian Diagram in four quadrants to further facilitate the formulation of improvement efforts that program managers must take.

Quadrant 1 (a main priority of performance improvement) indicates that the elements are very important for the community, but the service units have not worked according to the wishes of the community, thus causing dissatisfaction.

Quadrant 2 (maintaining performance) indicates that the elements considered important by the community have been successfully and satisfactorily implemented. Therefore, it is the obligation for the service units to maintain its performance.

Quadrant 3 (a low priority) indicates that the service elements are considered less important by the community and the implementation by the service units is mediocre, so they are considered less important and less satisfactory.

Quadrant 4 (excessive performance) indicates that the elements of service are considered less important by the community, but very well implemented by the service units, so it considered very satisfying and excessive.
The scale used in measuring satisfaction is Likert scale consisting of five degrees of expectations or importance and performance, as can be seen in Table 1. The degrees of importance ranges from unimportant to very important. Performance levels are rated from not good to very good.

Table 1

Measurement Scale

\begin{tabular}{cllc}
\hline No & $\begin{array}{c}\text { Degree of } \\
\text { Importance }\end{array}$ & Performance & Values \\
\hline 1 & Very important & Very good & 5 \\
2 & Important & Good & 4 \\
3 & Important & Good enough & 3 \\
& enough & & \\
4 & Less important & Poor & 2 \\
5 & Unimportant & Not good & 1 \\
\hline
\end{tabular}

\section{Posdaya Assistance Program}

The establishment of Posdaya in Bogor Regency and Bogor City was initiated by universities (PT) in Bogor such as Bogor Agricultural University (IPB), Ibnu Khaldun University (UIKA), Pakuan University (UNPAK) and Djuanda University (UNIDA). The activities carried out by the universities are in the form of Practical/Profession Work Course (KKN/KKP) and IPB Goes to Field (IGTF). The formation of Posdaya is also initiated by the local/city government, in addition to universities. 
Based on data in Table 2, the largest percentage of respondents $(46.4 \%)$ state that Posdaya assistance is done by universities, followed by the local government. The assistance offered by universities, local governments, and students in KKP/IGTF Program takes the third position, and the rest stated that the Posdaya assistance conducted by the students in the KKP/IGTF program. Posdaya assistance given through KKN, KKP or IGTF activities takes place only within the period of such activities (two months or two weeks) and then continues unscheduled by IPB P2SDM.

Table 2

Distribution of Posdaya in Bogor

Regency and Bogor City based on Posdaya Assistance

\begin{tabular}{lcc}
\hline \multicolumn{1}{c}{ Assistants } & Frequency & Percentage \\
\hline KKN/KKP/IGTF & 11 & 8.8 \\
$\begin{array}{l}\text { PT, Local } \\
\text { Government }\end{array}$ & 38 & 30.4 \\
PT & 58 & 46.4 \\
$\begin{array}{l}\text { KKN/KKP/IGTF, } \\
\text { PT and Local }\end{array}$ & 18 & 14.4 \\
Government & 125 & 100.0 \\
Total & & \\
\hline
\end{tabular}

The frequency of Posdaya assistance in one month according to the respondents is presented in Table 3. It can be seen from Table 4 that almost half of respondents state the frequency of assistance given is once a month or less. The rest say that assistance is given 2-3 times per month and 4 times or more in a month. This indicates that the assistance given is relatively rare. Assistance was relatively frequent to only some Posdayas due to budget constraints. According to Posdaya staff, the assistants' visits during the first years of the Posdaya assistance program were relatively routine. Afterward, the number of visits decreased. Over time, there were more Posdayas to be assisted, so the assistance could not reach routinely all Posdayas because they were far away from P2SDM office, and spread widely in Bogor Regency and Bogor City. Furthermore, there is a budgetary constraint, that is, a noncontinuous funding.

This is in line with the finding of Mukhlishah et al. (2014) in cocoa farmers, and Firmansyah et al. (2015) and Yumi et al. (2012) on farmers around the forest. Visits of assistance to farmers in each region were relatively rare due to a limited program budget, extension work area and difficult access to certain villages. The results of the study by Mujiburrahmad et al. (2014) found that the frequency of these extension visits was affected by the extent of the extension work area. The wider the extension work area, the visit to the farmer group would decrease because of the long distance between the regions.

This is different from the assistance given when certain programs are still running. Assistance was routinely carried out throughout the period of the program, as found by Mutmainna and Sumarti (2014) and Mutmainah and Sumardjo (2014). In the CSR (Corporate Social Responsibility) program of local economic empowerment (Mutmainna and Sumarti 2014), technical assistants in the field provided intensive assistance and stayed in the target villages. Mutmainah and Sumardjo (2014) found that intensive assistance was carried out because the farmers' groups would be involved in a contest in West Java.

\section{Table 3 \\ Distribution of Posdaya Personnel's Opinions on Frequency of Posdaya Assistance in One Month in Bogor Regency and Bogor City}

\begin{tabular}{ccc}
\hline $\begin{array}{c}\text { Assistance } \\
\text { Frequency }\end{array}$ & Frequency & Percentage \\
\hline$\leq 1$ time/month & 62 & 49.6 \\
$2-3$ times/month & 38 & 30.4 \\
$\geq 4$ times/month & 25 & 20.0 \\
Total & 125 & 100.0 \\
\hline
\end{tabular}

The duration of Posdaya assistance according to the respondents is presented in Table 4.

\section{Table 4}

Distribution of Posdaya Personnel's Opinions about Assistance Duration in Bogor Regency and Bogor City

\begin{tabular}{ccc}
\hline $\begin{array}{c}\text { Duration of } \\
\text { Assistance }\end{array}$ & Frequency & Percentage \\
\hline $\begin{array}{c}\leq 30 \text { minutes/ } \\
\text { meeting }\end{array}$ & 17 & 13.6 \\
$1-2$ hours/meeting & 76 & 60.8 \\
$\geq 3$ hours/meeting & 32 & 25.6 \\
Total & 125 & 100.0 \\
\hline
\end{tabular}

Based on the data in Table 4, the assistance most often given lasted from 1 to 
2 hours for each meeting, followed by 3 hours or more. The remaining respondents stated that the assistance lasted about half an hour or less. Assistance of 1-2 hours per meeting was considered sufficient by the Posdaya personnel. However, due to the relatively low frequency of assistance, it was felt inadequate by the Posdaya personnel. A limited time of assistance was also found by Dalimunthe and Murdianto (2013) in the MFI (Micro Financing Institution) program activities at Posdaya. MFI officers provided inadequate information, so some respondents still did not know and understand in detail about the functions and types of savings provided by MFI.

In terms of the method of assistance, most of them( $83.2 \%)$ was given in face-toface communication, i.e. the assistant visited Posdaya and met face-to-face (Table 5).

Table 5

Distribution of Posdaya Personnel's Opinions about Methods of Assistance in Bogor Regency and Bogor City

\begin{tabular}{lcc}
\hline \multicolumn{1}{c}{$\begin{array}{c}\text { Methods of } \\
\text { Assistance }\end{array}$} & Frequency & Percentage \\
\hline $\begin{array}{l}\text { Face-to-face } \\
\text { communication }\end{array}$ & 104 & 83.2 \\
Email & 1 & 0.8 \\
SMS & 1 & 0.8 \\
Others & 1 & 0.8 \\
$\begin{array}{l}\text { Face-to-face } \\
\text { communication, }\end{array}$ & 2 & 1.6 \\
$\begin{array}{l}\text { email } \\
\text { Face-to-face }\end{array}$ & 15 & 12.0 \\
$\begin{array}{l}\text { communication, } \\
\text { SMS }\end{array}$ & & \\
$\begin{array}{l}\text { Face-to-face } \\
\text { communication, }\end{array}$ & 1 & 0.8 \\
email, SMS & & \\
Total & 125 & 100.0 \\
\hline
\end{tabular}

Another way was a combination of face-to-face communication and SMS. Other methods (SMS only, email only or a combination of the three) were very rare. This is in line with the study results of Rasyid et al (2015) and Anwas et al. (2009) who found that the use of media by assistants tended to be low. On the other hand, this method of assistance with face-to-face communication gives the benefit that the problems found in the field can be identified and solved immediately. This was also identified by Sadono (2012), during the field visits and discussion with the subject of extension that the extension worker could identify directly the problem faced by the community so that it could be immediately solved. This is the difference with the study result of Nugroho et al. (2016) who found that the mass media is one of the most effective means of communication in socializing and disseminate information to the public.

Posdaya assistance material in Bogor Regency and Bogor City based on respondent's opinion is presented in Table 6. It shows that half of the Posdaya personnel stated that the assistance material was a combination of information on Posdaya activities, motivating, problem solving and institutional strengthening of Posdaya. The material is felt by the personnel adequately suitable to the needs of Posdaya.

\section{Table 6}

Distribution of Posdaya Personnel's Opinions about the Assistance Material in Bogor Regency and Bogor City

\begin{tabular}{|c|c|c|}
\hline Assistance material & Frequency & Percentage \\
\hline $\begin{array}{l}\text { a. Information } \\
\text { about posdaya } \\
\text { activities }\end{array}$ & 22 & 17.6 \\
\hline $\begin{array}{l}\text { b. Posdaya } \\
\text { problem } \\
\text { solution }\end{array}$ & 0 & 0.0 \\
\hline $\begin{array}{l}\text { c. Giving } \\
\text { motivation }\end{array}$ & 8 & 6.4 \\
\hline $\begin{array}{l}\text { d. Institutional } \\
\text { strengthening } \\
\text { of Posdaya }\end{array}$ & 2 & 1.6 \\
\hline e. Others & 1 & 0.8 \\
\hline $\begin{array}{l}\text { f. Answering a } \\
\text { and b }\end{array}$ & 4 & 3.2 \\
\hline $\begin{array}{l}\text { g. Answering a } \\
\text { and } \mathrm{c}\end{array}$ & 13 & 10.4 \\
\hline $\begin{array}{l}\text { h. Answering a } \\
\text { and d }\end{array}$ & 1 & 0.8 \\
\hline $\begin{array}{l}\text { i. Answering b } \\
\text { and } c\end{array}$ & 1 & 0.8 \\
\hline $\begin{array}{l}\text { j. Answering a, } \\
b \text {, and c }\end{array}$ & 6 & 4.8 \\
\hline $\begin{array}{l}\text { k. Answering a, c, } \\
\text { and d }\end{array}$ & 4 & 3.2 \\
\hline $\begin{array}{l}\text { I. Answering a, } \\
\text { b, c and d }\end{array}$ & 63 & 50.4 \\
\hline Total & 125 & 100.0 \\
\hline
\end{tabular}

With the main method through visits (Table 5), despite the relatively rare visits (Table 3), the assistant could identify the problems/needs of Posdaya so that the material given in the assistance met the needs of the personnel. This is in line with Sadono (2012) who found that with the method of 
visits, extension workers could identify the farmers' problems/needs for information. Thus, the information provided has been in line with the needs of farmers.

The business type undertaken by each Posdaya or its members varies considerably, especially in the economic field (Sadono et al., 2014a). This, of course, requires a variety of handling as well, needing assistance from the related experts. In relation to technical aspects, such as how to carry out healthy food processing and so on, P2SDM invites experts in their respective fields who are willing to share their knowledge with Posdaya.

The assistance locations are presented in Table 7. It can be seen from Table 7 that assistance was mostly (91.2\%) conducted in Posdaya's village, i.e. in the Posdaya secretariat/region. The remaining of less than $10 \%$ assistance took place in the assistant's office or others. This was the case when there was a meeting with several Posdayas, so it was held in the assistant's office (P2SDM IPB) or elsewhere (e.g. in Posdaya other than the respondents' Posdaya) in training activities or meetings with Posdaya cadres. Training activities or coordination involving many Posdayas are generally conducted in P2SDM office because the location is strategic enough to access from various areas of Posdaya. Such activities involving many Posdayas are also to introduce Posdaya products, so that each Posdaya personnel can recognize the products of other Posdayas, and to expand the marketing range of each Posdaya product as well.

\section{Table 7 \\ Distribution of Posdaya Personnel's Opinions about Assistance Locations in Bogor Regency and Bogor City}

\begin{tabular}{crc}
\hline $\begin{array}{c}\text { Assistance } \\
\text { Location }\end{array}$ & Frequency & Percentage \\
\hline Village & 114 & 91.2 \\
Assistant's office & 5 & 4.0 \\
Others & 6 & 4.8 \\
Totals & 125 & 100.0 \\
\hline
\end{tabular}

\section{Satisfaction of Posdaya Personnel toward Assistance Program}

One of the supporting factors for the success of community empowerment is assistance. The dominant role in Posdaya assistance activities is that of the assistant who coordinates with the Posdaya personnel.
The assistance offered is in the form of visits to Posdaya, consultation with personnel or cadres, looking at other successful Posdaya activities, and various discussions, seminars or training activities. The role of assistants, besides giving guidance, also helps with the preparation of proposals for activities to be submitted to outside parties. When there are problems in the Posdaya, a coordinator or cadre consults with the assistant for a solution

The assistance analysis by Posdaya personnel refers to the assisting elements of enabling, strengthening, protection, support, maintenance, frequency, time, and cost (Table 8). Assessment by Posdaya personnel on the elements of assistance provided at the time of its formation and the current condition is very useful in formulating the forms of assistance that will be done in the follow-up.

Based on the suitability analysis, the personnel considered that the assisting elements had a suitability level above $80 \%$, except for P6 (assistance frequency), which is below $80 \%$. The personnel considered that both formal and informal meetings with the assistants were relatively inadequate (Sadono et al., 2014a). The relatively rare visits were due to the wide coverage of assistance services and limited budget as a result of a non-continuous budgeting. Therefore, the assistance performance that emphasizes the quantity is still needed by the personnel because they do not feel confident to work alone. In this regard, Zulfida et al. (2015) found a decrease in total productivity factor index (Malmquist Index) in the performance of PNPM Mandiri Perdesaan. This indicates that personnel in the village institutions such as Community Empowerment Institutions (LPM) still have inadequate capability in preparing a plan of activities in rural development, thus causing inefficient financing. Therefore, Zulfida et al. (2015) view that several factors need attention, namely the socialization of program objectives to increase community participation, training and assistance. This is to enable the rural households (especially poor households) to have greater access to social capital through participation in community activities (Nasution et al., 2014).

On the other hand, a quality-oriented assistance has led to a positive attitude of the personnel to run the posdaya programs. This indicates that the assistance is not sufficient only during the specified assistance period, so there is the need for time flexibility, i.e. continuous assistance until the personnel is 
Table 8

Degree of Importance, Performance, Gap, and Suitability of Posdaya Assistance Bogor Regency and Bogor City

\begin{tabular}{lcccc}
\hline \multicolumn{1}{c}{ Elements } & Importance & Performance & Gap & Suita-bility \\
\hline Enabling & 17,29 & 14,30 & 2,99 & 82,70 \\
\hline Strengthening & 17,22 & 13,92 & 3,30 & 80,83 \\
\hline Protection & 17,24 & 14,66 & 2,58 & 85,02 \\
\hline Support & 17,30 & 14,65 & 2,65 & 84,68 \\
\hline Maintenance & 16,91 & 14,13 & 2,78 & 83,59 \\
\hline Assistance Frequency & 15,23 & 9,47 & 5,76 & 62,18 \\
\hline Assistance time & 13,03 & 10,60 & 2,43 & 81,38 \\
\hline Assistance cost & 14,18 & 12,20 & 1,98 & 86,02
\end{tabular}

able to run posdaya independently. In other words, there is no time restriction for posdaya assistance.

The result of CSI analysis shows that Posdaya personnel are satisfied (very good) towards Posdaya assistance program. The elements of the personnel's satisfaction are P3 (protection) and P4 (support). They feel secured with the activities carried out because they are treated fairly and in an atmosphere of mutual help. Assistants motivate them to be comfortable in working and have the courage to take risks.

In addition, the assistants are felt by the personnel to have strengthened self-confidence and inspired them to be independent. Working patiently demonstrated by the assistants has helped the personnel to find and open business alternatives and work on their duties well. The assistance program has been able to empower the personnel in managing Posdaya. This is in line with the resulted study by Sadono et al. (2014b) who found that empowering farmers in groups affected the level of farmer empowerment.

This is different from the result of the study by Tahitu (2013) who found that the level of farmers' satisfaction with the accuracy of agricultural extension services varied from less satisfied to very satisfied. Extension services were perceived as inadequate in assisting the needs of farmers, especially when farmers faced a problem and really expected extension assistance. Farmers often found it difficult to get help, including extension assistance. This difficult situation became worse when farmers could not make decisions quickly and accurately. Farmers usually could only surrender to such a condition.
Based on the resulted mapping of elements in the IPA quadrant, no assistance elements are of a major priority for improvement. However, three elements need improvement on a low priority, especially the aspects of frequency, followed by time and cost of assistance (Figure 2). The personnel considers that formal and informal meetings with the assistants are still inadequate, both individually and in groups, poorly scheduled and when the personnel work out of the Posdaya working area are not always accompanied by an assistant.

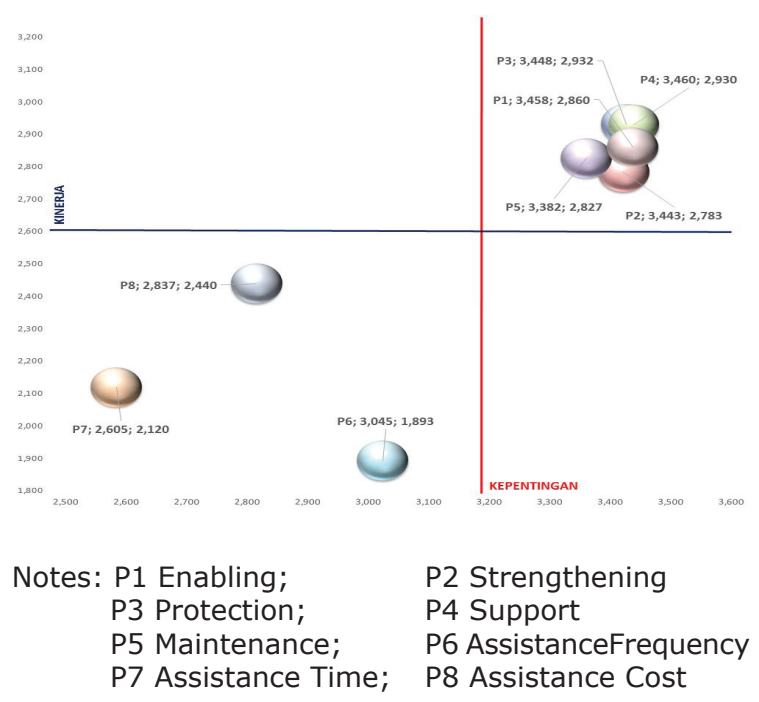

Figure 2.

Quadrant for Improvement of Posdaya Assistance Pattern in Bogor District and City

\section{Conclusions}

Posdaya assistance is given through face-to-face communication during the visits to the targeted Posdaya, meeting 
with Posdaya's staff in one of Posdayas, or gathering in the assistant's office. Effective assistance not only gives the material orally, but at the same time does a real practice and regularly, and monitor the location to ensure that things are done accordingly or to make improvements if needed.

Assistance elements (enabling, strengthening, protection, support, maintenance, time, and cost) are already good, except for the assistance frequency. The personnel are very satisfied (very good) towards the assistance program. The elements of the personnel satisfaction are protection and support. The resulted IPA analysis indicates that the pattern of assistance is in the satisfaction category (a value of 0.66 ), suggesting that some elements still require improvement in performance, especially assistance frequency, followed by time and cost of assistance.

Assistance activities have been able to improve the role of Posdaya in improving the community capacity to attain a better living standard. Some assistance elements still need improvement in performance, especially the assistance frequency, followed by time, and cost. Thus, assistance needs to operate more regularly at all Posdayas, with an adequate time (2-3 hours). Assistance to Posdaya is given not only in the forms of lecture and training, but also with real practice so that the Posdaya personnel capacity will becomes better.

\section{References}

Agustina, D. (2011). Persepsi dan Motivasi Berperanserta dalam Pos Pemberdayaan Keluarga (Posdaya): Kasus Peserta Posdaya Mandiri Terpadu di RW 01, Desa Cikarawang, Kecamatan Dramaga, Kabupaten Bogor. (Skripsi). Institut Pertanian Bogor. Bogor.

Anwas, O.M., Sumardjo, Asngari, P.A., and Tjitropranoto, P. (2009). Faktor-faktor yang Mempengaruhi Penyuluh dalam Pemanfaatan Media. Jurnal Penyuluhan, Vol. 05 No. 2: 155-166. September 2009.

Dalimunthe, N.C.J., and Murdianto. (2013). Analisis Lembaga Keuangan Mikro Posdaya Kenanga terhadap Tingkat Pendapatan Pelaku Usaha Mikro di Kelurahan Situgede, Kota Bogor. Jurnal Penyuluhan, Vol. 09 No. 2: 156-171. September 2013.

Firmansyah, Amanah, S., and Sadono, D. (2015). Motivasi, Kepuasan Kerja dan Kinerja Penyuluhan Kehutanan di Kabupaten Cianjur Jawa Barat. Jurnal Penyuluhan, Vol. 11 No. 1: 11-22, Maret 2015.

Ife, J., and Tesoriero, F. (2002). Community Development: Community-based Alternatives in an Age of Globalization. Third Edition. NSW: Pearson Education Australia.

Mujiburrahmad, Muljono, P., and Sadono, D. (2014). Kinerja Penyuluh Pertanian di Kabupaten Pidie Provinsi Aceh dalam Melaksanakan Tugas dan Fungsinya. Jurnal Penyuluhan, Vol. 10 No. 2: 141150. September 2014

Mukhlishah, N., Saleh, A., and Sadono, D. (2014). Aktivitas Komunikasi Organisasi dan Kinerja Pendamping dalam Program Gernas Kakao di Kabupaten Polewali Mandar. Jurnal Komunikasi Pembangunan, Vol. 12 No. 2: 49-59. Juli 2014.

Muljono, P. (2014). Preliminary Mapping of Posdaya Performance as Family Empowerment Program. Journal of Sustainable Development, Vol. 7 Issue 6: 18-26. December 2014.

Muljono, P., Burhanuddin, and Bachtiar, Y.(2009). Upaya Pemberdayaan Masyarakat dan Pengentasan Kemiskinan melalui Model Posdaya. Laporan Penelitian. Kerjasama Dikti dan IPB. Bogor

Muljono, P., Kusharto, C.M., and Rochimawati, N. (2010). Pengembangan Posdaya (Pos Pemberdayaan Keluarga) Upaya Pemberdayaan Masyarakat Lingkar Kampus. Laporan Penelitian Strategis Aplikasi. Kerjasama Dikti dan IPB. Bogor.

Muljono, P., Bachtiar, Y., Mintarti, and Soewondo, P.D.M.H.K. (2011). 101 Cara Mengenal Posdaya. IPB Press, Bogor.

Mutmainah, R., and Sumardjo. (2014). Peran Kepemimpinan Kelompok Tani dan Efektivitas Pemberdayaan Petani. Sodality: Jurnal Sosiologi Pedesaan, Vol. 08 No. 3: 213-232. Desember 2014.

Mutmainna, and Sumarti, T. (2014). Hubungan Tingkat Penerapan Prinsip Pengembangan Masyarakat dengan Keberhasilan Program CSR PT Pertamina. Sodality: Jurnal Sosiologi Pedesaan, Vol. 08 No. 3: 201212. Desember 2014.

Nasution, A.R., Rustiadi, E., Juanda, B., and Hadi, S. (2014). Dampak Modal Sosial terhadap Kesejahteraan Rumah Tangga Perdesaan di Indonesia. Mimbar: Jurnal Sosial dan Pembangunan, Vol. 30, No. 2: 137-148. Desember 2014.

Nugroho, D.R., Hubeis, A.V.S., Saleh, A., and Priatna, W.B. (2016). Model of 
Communication in Corporate Social Responsibility Program to Empower Communities. Mimbar: Social and Development Journal, Vol. 32 No. 2: 254266. December 2016.

Rahmawati, A. (2012). Peran Lembaga Keuangan Mikro Posdaya dalam Meningkatkan Kesejahteraan Anggota. (Skripsi). Institut Pertanian Bogor. Bogor. Rasyid, A., Saleh, A., Cangara, H., and Priatna, W.B. (2015). Komunikasi dalam CSR Perusahaan: Pemberdayaan Masyarakat dan Membangun Citra Positif. Mimbar: Jurnal Sosial dan Pembangunan, Vol. 31, No. 2: 507-518. Desember 2015.

Sadono, D. (2012). Model Pemberdayaan Petani dalam Pengelolaan Usahatani Padi di Kabupaten Karawang dan Cianjur, Provinsi Jawa Barat. (Disertasi). Institut Pertanian Bogor.

Sadono, D., Saharuddin, dan Yusalina. (2014a). Indeks Kepuasan Masyarakat terhadap Program Posdaya. Jurnal Kesejahteraan Sosial, Vol. 01 No. 1: 1-12. Februari 2014.

Sadono, D., Sumardjo, Gani, D.S., and Amanah, S. (2014b). Farmer Empowerment in The Management of Rice Farming in Two Districts in West Java. Journal of Rural Indonesia. Vol. 02 Issue 1: 105-126. June 2014.

Slamet, M. (2000). Pemberdayaan Masyarakat dalam Ida Yustina dan A. Sudradjat (eds). 2003. Membentuk Pola Perilaku Manusia Pembangunan: Didedikasikan kepada Prof. Dr. H.R. Margono Slamet. Bogor. IPB Press.
Supranto, J. (2011). Pengukuran Tingkat Kepuasan Pelanggan untuk Menaikkan Pangsa Pasar. Rineka Cipta. Jakarta.

Suyono, H. and Haryanto, R. (2007). Buku Pedoman Pembentukan dan Pengembangan Pos Pemberdayaan Keluarga (Posdaya). Yayasan Dana Sejahtera Mandiri. Jakarta.

Tahitu, M.E. (2013). Kualitas Pelayanan Penyuluhan Pertanian dan Kepuasan Petani dalam Pengembangan Usahatani (Kasus di Desa Sukadamai Kecamatan Dramaga Kabupaten Bogor). Jurnal Penyuluhan, Vol. 09 No. 2: 146-155. September 2013.

Virianita, R., Bakhtiar, Y., and Asikin, S. (2011). Posdaya (Pos Pemberdayaan Keluarga) Mitra Tani Desa Cikarawang Kec. Dramaga Kab. Bogor. Laporan IPTEK bagi Masyarakat. Kerjasama Dikti dan IPB. Bogor.

Yumi, Sumardjo, Gani, D.S., and Sugihen B.G. (2012). Dukungan Kelembagaan Masyarakat dalam Pembelajaran Petani untuk Pengelolaan Hutan Rakyat Lestari di Kabupaten Gunung Kidul Provinsi Daerah Istimewa Yogyakarta dan Kabupaten Wonogiri Provinsi Jawa Tengah. Jurnal Penyuluhan, Vol. 08 No. 2: 141-157. September 2012.

Zulfida, I., Fauzi, A., Rustiadi, E., and Syaukat, Y. (2015). Kinerja Program Nasional Pemberdayaan Masyarakat Mandiri Perdesaan di Kabupaten Bandung. Mimbar: Jurnal Sosial dan Pembangunan, Vol. 31, No. 2: 307318. Desember 2015. 